\title{
ULOGA BURZE VRIJEDNOSNICA U SUSTAVU ODRŽIVIH I ODGOVORNIH FINANCIJSKIH ULAGANJA: ANALIZA POSLOVNOG SLUČAJA
}

\author{
THE ROLE OF THE STOCK EXCHANGE IN SUSTAINABLE \\ AND RESPONSIBLE INVESTMENT SYSTEM: \\ A CASE STUDY ANALYSIS
}

\begin{abstract}
SAŽETAK: Održivost na financijskim tržištima je višeslojna tema, o kojoj se sve više raspravlja u znanstvenim i stručnim krugovima, a na čiju su važnost počela ukazivati i najviša politička tijela poput Europske komisije. U postizanju takve održivosti važnu ulogu imaju burze vrijednosnica, središnje pozicionirane između ulagača, listiranih poduzeća i regulatornih tijela, povezujući ponudu i potražnju na tržištima kapitala. Cilj rada je prikazati ulogu burze vrijednosnica u poticanju održivih i odgovornih financijskih ulaganja, kroz analizu poslovnog slučaja grupe Deutsche Boerse. Primjenom metode istraživanja za stolom, analize dokumentacije i provedenih dubinskih intervjua, prikupljeni su primarni i sekundarni izvori podataka koji su omogućili bolje razumijevanje dobre prakse tržišta. Prepoznate su različite inicijative poticanja takvih ulaganja na strateškoj i operativnoj razini grupe Deutsche Boerse. Strateški važnima istaknuti su kreiranje upravljačkog tijela za održivo poslovanje, inicijative razvoja održivog financiranja i pokretanje platforme za zelene obveznice. Na operativnoj razini to su kreiranje operativnih grupa za održivi razvoj, suradnja s pružateljima nefinancijske analitike, poticanje transparentnosti, razvoj usluga održivog financiranja te provođenje interne ankete među interesno-utjecajnim skupinama.

KLJUČNE RIJEČI: burze vrijednosnica, održiva i odgovorna financijska ulaganja, financijski sustav, analiza poslovnog slučaja, održive burze vrijednosnica.
\end{abstract}

JEL: G23, M14.

Lucija Basić, mag. oec., Deutsche Boerse AG, Mergenthalerallee 61, 65760 Eschborn, Njemačka.

** Doc. dr. sc. Ana Ivanišević Hernaus, Ekonomski fakultet Sveučilišta u Zagrebu, Trg J. F. Kennedyja 6, Zagreb. 


\begin{abstract}
Sustainability in financial markets is a multilayer topic, increasingly being discussed in academia and business practice, and the importance of which has been raised by top political bodies such as the European Commission. Stock exchanges, centrally positioned between investors, listed companies and regulatory bodies, and linking supply and demand at capital markets, play an important role in achieving such sustainability. The aim of the paper is to present the role of the stock exchange in promoting sustainable and responsible investment, through a case study analysis of Deutsche Boerse Group. Using a desktop research method, analysis of documentation and in-depth interviews, primary and secondary sources of data were collected, that provided a better understanding of good practice of the market. Various initiatives have been identified to encourage such investment at strategic and operational level at Deutsche Boerse Group. The creation of a governing body for sustainable business, the development of sustainable financing initiatives and the launching of the green bond platform have been recognized as strategically important. At the operational level, these include the creation of operational groups for sustainable development, cooperation with non-financial analytics providers, fostering transparency, the development of sustainable financing services, and conducting an internal stakeholder survey.

KEY WORDS: stock exchanges, sustainable and responsible investment, financial system, case study analysis, sustainable stock exchanges.
\end{abstract}

JEL: G23, M14.

\title{
1. UVOD
}

Održivo financiranje predstavlja postupak uzimanja u obzir okolišnih i društvenih aspekata u odlukama o ulaganju, što dovodi do većeg ulaganja u dugoročnije i održive djelatnosti (Europska komisija, 2018.). Konkretno, okolišni aspekti odnose se na ublažavanje klimatskih promjena i prilagodbu tim promjenama te općenito na okoliš (npr. obuhvaćaju onečišćenje zraka i vode, iscrpljivanje resursa i gubitak biološke raznolikosti) i s njime povezane rizike (npr. prirodne katastrofe). Društveni aspekti mogu se odnositi na pitanja nejednakosti, uključivosti, radnih odnosa te ulaganja u ljudski kapital i društvenu zajednicu. Upravljanje javnim i privatnim institucijama, uključujući strukture upravljanja, odnose među zaposlenicima i naknade izvršnim tijelima, ima važnu ulogu u uključivanju društvenih i okolišnih aspekata u postupak odlučivanja (Europska komisija, 2018.).

Financijski sustav prepoznat je kao dio rješenja za postizanje zelenijeg i održivog gospodarstva. Pritom se naglašava nužnost preusmjeravanja privatnog kapitala na održiva i odgovorna financijska ulaganja u cilju razvoja održivog gospodarskog rasta, osiguranja stabilnosti financijskog sustava i poticanja veće transparentnosti i dugoročnosti u gospodarstvu. Takvo je razmišljanje ključno i za EU-ov projekt unije tržišta kapitala (capital markets union) (Europska komisija, 2018.). Politike i instrumenti tržišta kapitala koji potičući održiva i odgovorna ulaganja podržavaju Program održivog razvoja Ujedinjenih naroda do 2030. godine postaju sve važnija pitanja (Sustainable Stock Exchanges Initiative, 2018.). Održivo financiranje obuhvaća projekte i ulaganja koji će, između ostaloga, doprinijeti i održivom razvoju (v. $\mathrm{Ng}, 2019$.).

U tome značajnu ulogu imaju financijske institucije burzi vrijednosnica. Središnje pozicionirane između ulagača, listiranih poduzeća i regulatornih tijela, burze vrijednosnica 
nastoje učinkovito i transparentno povezati ponudu i potražnju na tržištima kapitala. Sve veći interes burzi vrijednosnica širom svijeta za održivost u poslovanju upućuje na tržišnu potražnju za nefinancijskim informacijama - okolišnim, društvenim, upravljačkim (engl. Environmental, Social, Governance - ESG) - koje mogu biti korisne i za daljnji razvoj koncepta održivih i odgovornih financijskih ulaganja. Potreba za društveno odgovornim poslovanjem i transparentnim izvještavanjem učinila je nefinancijske informacije jednako važnima kao i financijske informacije (v. Dečman et al., 2019.).

Burze vrijednosnica u Europskoj uniji predstavljaju svjetske predvodnike kad je riječ o transparentnosti nefinancijskih informacija o izdavateljima vrijednosnih papira (pri čemu je, prema Sustainable Stock Exchanges Initiative (2018.), Deutsche Boerse jedna od prvih pet takvih burzi vrijednosnica). Međutim, unatoč tome, održivo financiranje potrebno je još u značajnoj mjeri poticati. Primjerice, burze vrijednosnica, uz razvoj i primjenu jasnih standarda, mogu pružiti potporu razvoju tržišta zelenih obveznica (European Commission, 2017.). Njihovu ulogu kao specifične interesno-utjecajne skupine na tržištu održivih i odgovornih financijskih ulaganja neophodno je detaljnije istražiti i predstaviti jer, unatoč sve većem interesu za održivo financiranje (UNEP, 2017.), znanstvena literatura još uvijek nedovoljno objašnjava takav način poticanja ekonomskog rasta i razvoja (npr. Oh et al., 2013.). Dok među znanstvenicima postoji konsenzus o pozitivnoj vezi između financijskih tržišta koja dobro funkcioniraju i ekonomskog razvoja, nisu razvijene praktične smjernice za izgradnju uspješnog financijskog tržišta (UNCTAD i World Federation of Exchanges, 2017.).

Cilj rada je prikazati i istaknuti ulogu burze vrijednosnica u poticanju održivih i odgovornih financijskih ulaganja. Kroz analizu poslovnog slučaja grupe Deutsche Boerse, jedne od vodećih svjetskih burzi i organizatora tržišta održivog financiranja u Njemačkoj, bit će prikazan način na koji ta financijska institucija omogućava i potiče održiva i odgovorna financijska ulaganja. Primjenom metode istraživanja za stolom te analize dokumentacije i provedenih dubinskih intervjua, prikupljeni su primarni i sekundarni izvori podataka koji su omogućili bolje razumijevanje dobre prakse ovog tržišta. Polazeći od teorije važnosti interesno-utjecajnih skupina (engl. stakeholder salience theory) istražen je financijski sustav s fokusom na odnose između različitih sudionika tržišta održivih i odgovornih financijskih ulaganja.

U teorijskom smislu, ovaj rad čitatelju pruža konceptualni okvir za bolje razumijevanje ponude i potražnje tržišta održivih i odgovornih financijskih ulaganja, uključujući i prikaz svjetskih inicijativa za njegov razvoj. Dodatno, burze vrijednosnica su u ulozi financijskog posrednika prepoznate i istaknute kao važan sudionik ovog tržišta, o kojem u određenoj mjeri može ovisiti i stupanj realizacije ciljeva UN-ovog Programa održivog razvoja. Praktična vrijednost rada ogleda se kroz dubinski prikaz prakse djelovanja burze vrijednosnica u sustavu održivih i odgovornih financijskih ulaganja. Osim uvida u interne procese grupe Deutsche Borse, analizirana su i ponuđena i stručna razmišljanja o budućem smjeru razvoja ovog tržišta. 


\section{SUSTAV ODRŽIVIH I ODGOVORNIH FINANCIJSKIH ULAGANJA}

\subsection{Ponuda i potražnja tržišta održivih i odgovornih financijskih ulaganja}

Održivo i odgovorno financijsko ulaganje postalo je važno obilježje financijske djelatnosti (European Fund and Asset Management Association, 2016.) te predstavlja relevantno pitanje na institucionalnoj, nacionalnoj i supranacionalnoj razini (Ivanišević Hernaus, 2019.). Održivim i odgovornim financijskim ulaganjima na tržištu kapitala ulagači nastoje poticati društveno odgovorno poslovanje poduzeća, usmjeravajući financijska sredstva u ona poduzeća (ili organizacije) koja se ističu dobrom praksom društveno odgovornog poslovanja. Takva ulaganja omogućuju korištenje tradicionalnih tržišnih mehanizama radi doprinosa stvaranju održivog i zdravog društva (Ivanišević Hernaus, 2013.) i predstavljaju područje financija koje se snažno razvija. Financijski sektor pruža infrastrukturu i smjernice za održiva i odgovorna financijska ulaganja kroz, primjerice, ponudu održivih i odgovornih investicijskih fondova, djelovanje rejting organizacija specijaliziranih za društveno odgovorno poslovanje i raspoloživost tržišnih indeksa održivosti (Wagemans et al., 2013.).

Sustav održivih i odgovornih financijskih ulaganja čine različiti sudionici financijskog tržišta, od kojih se neki nadmeću ili surađuju kako bi kreirali i nudili financijske usluge. Unatoč prepoznatoj potrebi za održivim i odgovornim ponašanjem različitih interesno-utjecajnih skupina (banaka, korporativnih menadžera, upravljača održivim i odgovornim investicijskim fondovima, regulatornih tijela, rejting agencija, pojedinačnih i institucionalnih ulagača), uloge specifičnih interesno-utjecajnih skupina nisu istražene. Primjerice, dok je jasna uloga pojedinačnih i institucionalnih ulagača, investicijskih fondova održivih i odgovornih financijskih ulaganja ili regulatornih tijela kao sudionika tržišta ovih ulaganja, uloga drugih interesno-utjecajnih skupina, poput primjerice burzi vrijednosnica, još uvijek nije u dovoljnoj mjeri razjašnjena. U dosadašnjim istraživanjima, u najvećem dijelu literature, uloga burzi vrijednosnica u poticanju održivih i odgovornih financijskih ulaganja proučena je kroz korištenje ESG indeksa (Ortas i Moneva, 2011.; Vives i Badhwa, 2012.; Brzeszczynski i McIntosh, 2014.; Cunha i Samanez, 2014.; Janik i Batrkowiak, 2015.; i dr.). Primjerice, Vives i Badhwa (2012.) prepoznali su različite uloge koje takvi indeksi mogu imati, a Janik i Batrkowiak (2015.) su istražili njihov sastav i profitabilnost. U posljednjih nekoliko godina raste interes za izučavanjem inovativnih financijskih instrumenata poput zelenih obveznica (npr. Daszynska-Zygadlo et al., 2018.; Ng, 2018.; Banga, 2019.; Baulkaran, 2019.; Wisniewski i Zielinski, 2019.) i obveznica $s$ društvenim utjecajem (npr. Taraktas, 2015.; Pauly i Swanson, 2017.; Dayson et al., 2019.). Navedeni radovi istražuju izdanja takvih instrumenata i procjenu njihovog utjecaja na tržište. Manji broj radova istražuje druge uloge burzi vrijednosnica u održivim i odgovornim financijskim ulaganjima, kao što su svjetska Inicijativa Održivih burzi vrijednosnica (npr. Klagge i Zademach, 2018.) i nefinancijsko izvještavanje kao kriterij uvrštenja (npr. Fatima et al., 2015.; Horn et al., 2018.).

U cilju sustavnog pregleda interesno-utjecajnih skupina na tržištu održivih i odgovornih financijskih ulaganja i daljnjeg istraživanja njihovih uloga, u prethodnom tekstu navedene skupine moguće je grupirati u sljedeće tržišne komponente: ponuda tržišta održivih i odgovornih financijskih ulaganja, potražnja tržišta održivih i odgovornih financijskih ula- 
ganja, i financijski posrednici. Osnovna značajka održivih i odgovornih financijskih ulaganja je uzimanje u obzir, osim financijskih, i nefinancijskih informacija. Ključni sudionici koji uvažavaju nefinancijska pitanja, sa strane potražnje, su društveno odgovorna poduzeća. Sa strane ponude, ulagači pokazuju sve veći interes za održivim i odgovornim financijskim ulaganjima kao načinom na koji mogu diversificirati svoj portfelj i ostvariti financijske i nefinancijske ciljeve. Tu se javljaju različiti institucionalni i pojedinačni ulagači, a među njima se susreću i država kao ulagač te nevladine organizacije i zaklade, koje ulažu u skladu sa svojim vrijednostima. Slično kao i na tradicionalnim financijskim tržištima, posrednici imaju središnju ulogu povezujući strane ponude i potražnje, a sudjeluju i u samom razvoju sustava takvih ulaganja (v. OECD, 2019.). Obuhvaćaju različite upravljače imovinom kao što su investicijski fondovi, mirovinski fondovi, banke (njihove organizacijske jedinice zadužene za upravljanje ulaganjima) itd.

Kako bi se sustav održivih i odgovornih financijskih ulaganja mogao sagledati u cijelosti, potrebno je uzeti u obzir i širi kontekst, koji obuhvaća i regulatorni okvir, društveni sustav, porezni sustav itd., pritom uvažavajući nacionalne i regionalne posebnosti. Sveobuhvatni teorijski okvir sustava održivih i odgovornih financijskih ulaganja polazi od okvira tzv. financijskih ulaganja s utjecajem (engl. impact investment), kao jednog segmenta održivih i odgovornih financijskih ulaganja, razvijenog od strane OECD-a (2015.) i prikazanog na slici 1.

OKOLIŠNA, DRUŠTVENA I EKONOMSKA PITANJA

siromaštvo, nejednakost, obrazovanje, zapošljavanje, zdravlje, klimatske promjene, pristupačna i čista energija, starenje

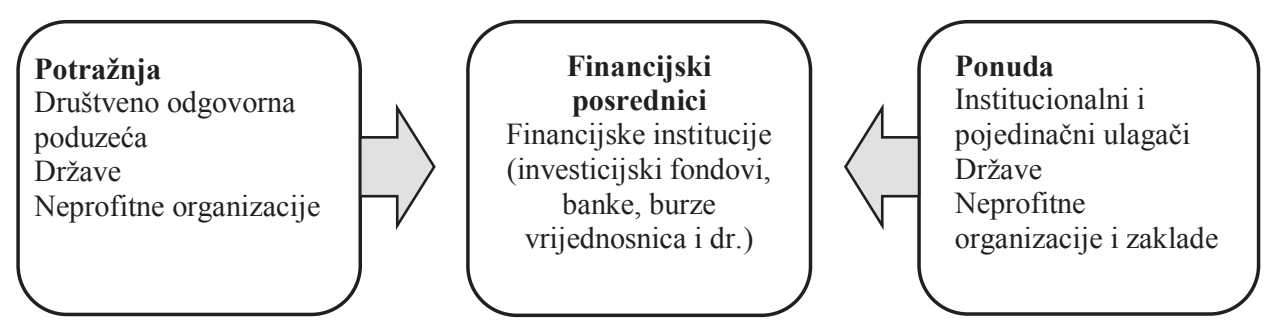

PODRŽAVAJUĆE OKRUŽENJE
društveni sustavi,_regulatorni i pravni okvir, porezi, stupanj razvoja financijskog tržišta

Slika 1. Teorijski okvir održivog i odgovornog investicijskog tržišta

Izvor: prilagođeno prema OECD (2015.).

\subsection{Stakeholderski pristup tržištu održivih i odgovornih financijskih ulaganja}

U literaturi postoji niz istraživanja koja nastoje izložiti poglede sudionika na svrhu svoje organizacije i njezinih aktivnosti u odnosu na različite interesno-utjecajne skupine (Brickson, 2007.). Sličan pristup odabran je i u ovom radu. Teorija važnosti interesno-utjecajnih skupina je primijenjena u analizi uloga i motiva različitih skupina sudionika tržišta 
održivih i odgovornih financijskih ulaganja. Kako bi se neizravno procijenila angažiranost i odnos između odabranih interesno-utjecajnih skupina, po uzoru na ranija istraživanja (npr. Magness, 2008.; Gifford, 2010.) primijenjen je Mitchellov model (1997.) kao sredstvo za identifikaciju i utvrđivanje prioritetnih interesno-utjecajnih skupina i njihovih zahtjeva (Neville et al., 2011.). Proširena verzija modela prilagođena održivim i odgovornim financijskim ulaganjima (Gifford, 2010.) obuhvatila je dimenzije utjecaja interesno-utjecajne skupine kao što su moć, legitimitet i hitnost. Moć je sposobnost kontrole resursa, legitimitet se odnosi na društveno prihvaćanje pitanja, a hitnost na to koliko je pitanje važno i aktualno. Ove su dimenzije od strane donositelja odluka društveno oblikovane i njihova je percepcija subjektivna (Wagemans et al., 2013.).

Pored prethodno izloženih subjekata ponude (institucionalni i pojedinačni ulagači, država, neprofitne organizacije i zaklade) i potražnje (društveno odgovorna poduzeća, država, neprofitne organizacije) koji su ujedno i glavni pokretači razvoja tržišta održivih i odgovornih financijskih ulaganja, prepoznate su i druge interesno-utjecajne skupine.

Snažni financijski centri utemeljeni su u skupini najrazvijenijih G7 zemalja i predstavljaju skupine različitih vrsta organizacija koje nude financijske usluge, upravljača imovinom, vlasnika imovine i drugih sudionika tržišta. Među najvećim financijskim centrima u svijetu prema visini dioničke tržišne kapitalizacije u 2018. godini su New York, Tokio, Šangaj, Hong Kong, Pariz i London. Prema navedenom kriteriju najveći centri u Europi su, uz Pariz i London, Frankfurt i Zürich (World Federation of Exchanges, 2019.). Kako bi se potaknulo sustavno djelovanje u cilju postizanja održivog financiranja, potrebno je surađivati sa svim sudionicima ovih skupina (Sustainable Stock Exchanges Initiative, 2017.).

Važnu ulogu na tržištu održivih i odgovornih financijskih ulaganja imaju financijske institucije u funkciji financijskih posrednika u širem smislu, posebice burze vrijednosnica. Dok će održive burze vrijednosnica biti detaljnije izložene u nastavku, kao novi trend javljaju se i socijalne burze vrijednosnica (engl. social stock exchanges) koje predstavljaju platforme za trgovanje isključivo društvenim poduzećima (najčešće manja poduzeća koja brzo rastu, iz sektora poput zdravstva, obrazovanja, zaštite okoliša, društvenog i cjenovno pristupačnog stanovanja, održivog šumarstva i organske poljoprivrede). Svojim djelovanjem takve burze doprinose uspostavljanju nedovoljno razvijenog regulatornog okvira održivog financiranja (Dadush, 2015.; Wendt, 2017.), a prva je otvorena 2013. godine u Velikoj Britaniji (Chhichhia, 2015.).

Sve veći interes ulagača za nefinancijskim informacijama potrebnima za provođenje sveobuhvatnih financijskih analiza i donošenje odluka o ulaganjima rezultirao je i većom potrebom za ESG analitikom. Sve veća vrijednost financijske imovine je predmet ESG istraživanja, a javljaju se i specijalizirani pružatelji usluga ESG analitike u obliku specijaliziranih rejting agencija. Njihovim radom ulagačima su na raspolaganju profinjeni investicijski alati, više raspoloživih načina za prikupljanje nefinancijskih informacija, veći broj indeksa koji se temelje i na ESG informacijama i primjena ESG čimbenika u različitim vrstama imovine, uključujući vrijednosnice s fiksnim prinosom i alternativna ulaganja (Vezer et al., 2017.).

Važnu interesno-utjecajnu skupinu na tržištu održivih i odgovornih financijskih ulaganja predstavlja država, prije svega u ulozi regulatora, koji omogućava uvjete za stvaranje podržavajuće okoline. Opći uvjeti poslovanja u zemlji mogu imati značajan utjecaj na razvoj financijskih tržišta općenito i tržišta održivih i odgovornih financijskih ulaganja posebno (v. 
npr. OECD, 2015.). Kako bi tržište takvih ulaganja dobro funkcioniralo, nužni su poticajan regulatorni okvir i strukture, kao i pojednostavljeni propisi i zahtjevi kod ulaganja (Thornley et al., 2011.). Osim regulatorne uloge, država može imati i ulogu tržišnog sudionika, kroz vlastito neizravno ili izravno sudjelovanje na tržištu održivih i odgovornih financijskih ulaganja (OECD, 2015.).

\subsection{Svjetske inicijative za razvoj tržišta održivih i odgovornih financijskih ulaganja}

Pozitivno stimulirajuće okruženje predstavlja važan čimbenik razvoja i šire primjene održivih i odgovornih financijskih ulaganja (OECD, 2019.). Neke od najznačajnijih svjetskih inicijativa u području održivog financiranja su UN-ova Načela odgovornog ulaganja, Standardi nefinancijskog izvještavanja Globalne inicijative za izvještavanje i UN-ova inicijativa održivih burzi vrijednosnica.

Standardi nefinancijskog izvještavanja Globalne inicijative za izvještavanje (Global Reporting Initiative - GRI) su prvi i najšire korišteni standardi nefinancijskog izvještavanja. Predstavljaju najbolju svjetsku praksu izvještavanja o širokom spektru ekonomskih, okolišnih i društvenih pitanja koja se od 1997. godine do danas redovito ažurira i unapređuje. Standardi obuhvaćaju zahtjeve, preporuke i smjernice organizacijama za nefinancijsko izvještavanje (GRI, 2018.), koji bi trebali pružiti informacije o pozitivnom ili negativnom utjecaju organizacije na održivi razvoj (GRI, 2019.). Takve informacije trebale bi omogućiti interesno-utjecajnim skupinama unutar i izvan organizacije oblikovanje mišljenja i informirano odlučivanje o doprinosu organizacije ciljevima održivog razvoja.

Desetak godina nakon Globalne inicijative za izvještavanje, u 2006. godini, definirana su UN-ova Načela odgovornog ulaganja (The United Nations' Principles for Responsible Investment - PRI). Na poticaj glavnog tajnika Ujedinjenih naroda, grupa od 20 najvećih svjetskih institucionalnih ulagača i 70 investicijskih stručnjaka te stručnjaka iz međuvladinih organizacija i predstavnika civilnog društva postavila je temelj za danas još uvijek najvažniju globalnu inicijativu odgovornog ulaganja (Woods i Urwin, 2010; Sandberg, 2013.), koja u 2019. okuplja više od 2.500 potpisnika (70 \% su upravljači ulaganjima, $18 \%$ vlasnici imovine, a $12 \%$ pružatelji usluga). Šest dobrovoljnih načela ulaganja nudi izbor mogućih aktivnosti za uključivanje nefinancijskih pitanja u investicijsku analizu (PRI, 2019.).

Pod okriljem Ujedinjenih naroda 2009. godine pokrenuta je i Inicijativa održivih burzi vrijednosnica (Sustainable Stock Exchanges Initiative) koja predstavlja platformu partnerskih burzi vrijednosnica nastalu kao odgovor na njihovu potrebu da, zajedno s ulagačima, poduzećima, regulatorima i donositeljima politika, dijele najbolje prakse i razmotre financijske izazove u okruženju s više interesno-utjecajnih skupina (Sustainable Stock Exchanges Initiative, 2018.). Inicijativa je doprinijela popularizaciji nekih segmenata održivih i odgovornih financijskih ulaganja jer ih je učinila pristupačnim širem krugu ulagača (Hartzell, 2007.; Wendt, 2017.). Ona također potiče burze vrijednosnica da ponude izdavateljima vrijednosnih papira smjernice o nefinancijskom izvještavanju, kao i vlastito izvještavanje o nefinancijskim pitanjima, od 2015. godine, koje je prilagođeno njihovom domaćem tržištu (Sustainable Stock Exchanges Initiative, 2017.). Inicijativa uključuje većinu svjetskih burzi vrijednosnica (Sustainable Stock Exchanges Initiative, 2018.). 


\section{ODRŽIVE BURZE VRIJEDNOSNICA}

\subsection{Važnost financijskog posredovanja na tržištu održivih i odgovornih financijskih ulaganja}

Održiva i odgovorna financijska ulaganja u značajnoj mjeri predstavljaju posredno financiranje. Financijski posrednici mogu imati središnju ulogu u razvoju sustava održivih i odgovornih financijskih ulaganja jer povezuju potražnju i ponudu takvih ulaganja, smanjujući asimetriju informacija između ulagača i subjekata u koje ulažu. Dodatno, oni pružaju nova inovativna rješenja ili nude savjete i pomoć u strukturiranju poslova i upravljanju financijskim sredstvima (OECD, 2015.). Njihova uloga posebice dolazi do izražaja na manje razvijenim tržištima, gdje često ne postoje odgovarajući tržišni mehanizmi preko kojih bi se izravno povezale ponuda i potražnja održivog financiranja.

\subsection{Suvremena uloga burze vrijednosnica u financijskom sustavu}

Burze vrijednosnica važan su sudionik tržišta održivih i odgovornih financijskih ulaganja koji svojim djelovanjem, kroz neprestanu prilagodbu ponude i potražnje za takvim ulaganjima, može potaknuti rast i održivost cjelokupnog gospodarstva (Sustainable Stock Exchanges Initiative, 2017.). Središnja pozicija između različitih sudionika financijskog tržišta omogućava alokaciju kapitala i u svrhu održivog financiranja.

Tradicionalna uloga i doprinos burzi vrijednosnica nedavno su prošireni i na poticanje održivih i odgovornih financijskih ulaganja. Kroz postavljanje i usvajanje tržišnih standarda društveno odgovornog poslovanja te uvođenje politika i instrumenata tržišta kapitala koji potiču prakse održivog financiranja, burze vrijednosnica mogu pristupiti izazovima okolišne i društvene naravi (npr. problemima koje donose klimatske promjene) i mogu podržati postizanje UN-ovih Ciljeva održivog razvoja (UNCTAD i World Federation of Exchanges, 2017.). Takva, suvremena uloga burzi vrijednosnica, kao sidrene institucije za poticanje održivosti na financijskim tržištima (UNEP, 2017.) predstavlja korak naprijed u odnosu na dosadašnja očekivanja vezana za dobro korporativno upravljanje i osiguravanje dostupnosti relevantnih informacija za ulagače.

Mnoge burze vrijednosnica već imaju značajnu ulogu u poticanju poduzeća na primjenu održivih praksi i nefinancijsko izvještavanje, nudeći smjernice i edukaciju za izdavatelje vrijednosnih papira te postavljajući za njih strože zahtjeve (Sustainable Stock Exchanges Initiative, 2015.). Održive burze vrijednosnica najčešce potiču održiva i odgovorna financijska ulaganja kroz ponudu ESG indeksa, pružanje savjetodavnih usluga vezano uz ESG pokazatelje, postavljanje pravila uključenja na burzu te izdavanje zelenih obveznica (Chesebrough et al., 2016.).

Prema podacima UN-ove Inicijative održivih burzi vrijednosnica (UNCTAD i World Federation of Exchanges, 2017.), krajem 2018. godine 78 burzi vrijednosnica obvezale su se na poticanje razvoja održivog i transparentnog tržišta pristupajući spomenutoj inicijativi. Dodatno, osnivanje Radne skupine za pitanja održivosti pri Svjetskom udruženju burzi vrijednosnica ukazuje na sve veću pozornost koja se tome pridaje. Slika 2. prikazuje burze vrijednosnica koje provode različite aktivnosti usmjerene prema poticanju održivosti na financijskim tržištima. Primjerice, najveći rast u uvođenju ESG tržišnih indeksa ostvaren 
je 2007. godine, izvještaji o održivosti široko se počinju objavljivati u 2011. godini, dok je značajan broj burzi vrijednosnica počeo uvoditi edukacije o ESG pitanjima u 2013. godini. U godini kasnije značajnije su predstavljene zelene obveznice, a 2015. godinu je obilježilo respektabilno povećanje obveznog nefinancijskog izvještavanja za izdavatelje i pisanih smjernica o takvom izvještavanju.

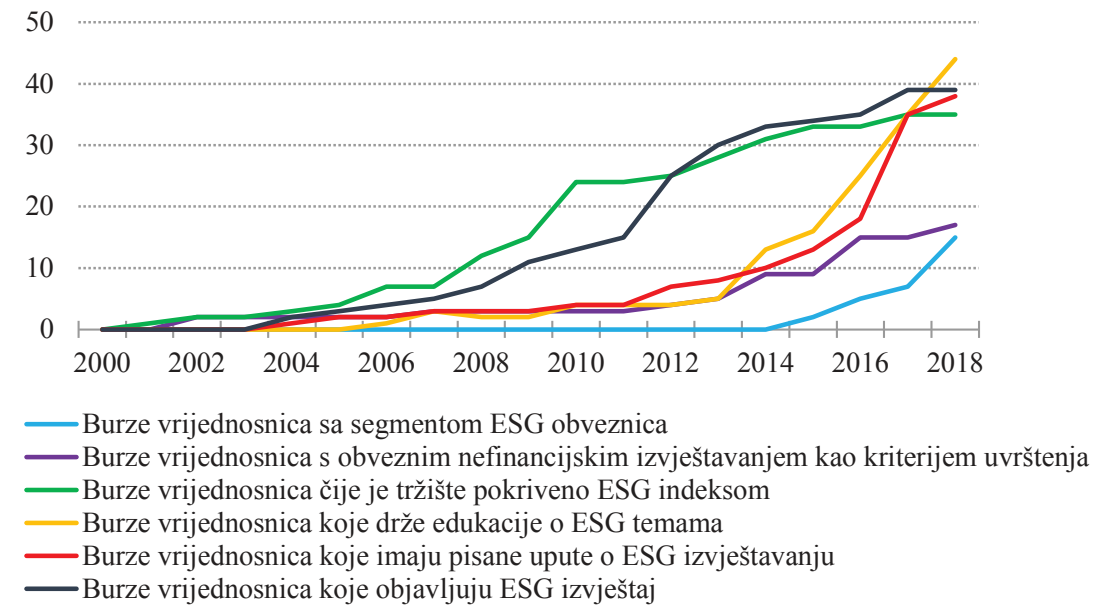

Slika 2. Aktivnosti burzi vrijednosnica u području održivosti na financijskim tržištima (prema broju burzi vrijednosnica), 2000. - 2018.

Napomena: Podatak za 2018. godinu odnosi se na treće tromjesečje.

Izvor: Sustainable Stock Exchanges Initiative (2018.).

Sposobnost burzi vrijednosnica da ostvare svoje temeljne uloge odnosno omoguće mobilizaciju resursa za održivi ekonomski rast i razvoj i dobro upravljanje ovisi o postojanju kombinacije relevantnih podržavajućih politika, procesa i institucijskih struktura (UNCTAD i World Federation of Exchanges, 2017.). Na slici 3. je prikazan Okvir rasta i održivog razvoja koji objedinjuje glavne uloge i aktivnosti održivih burzi vrijednosnica. 


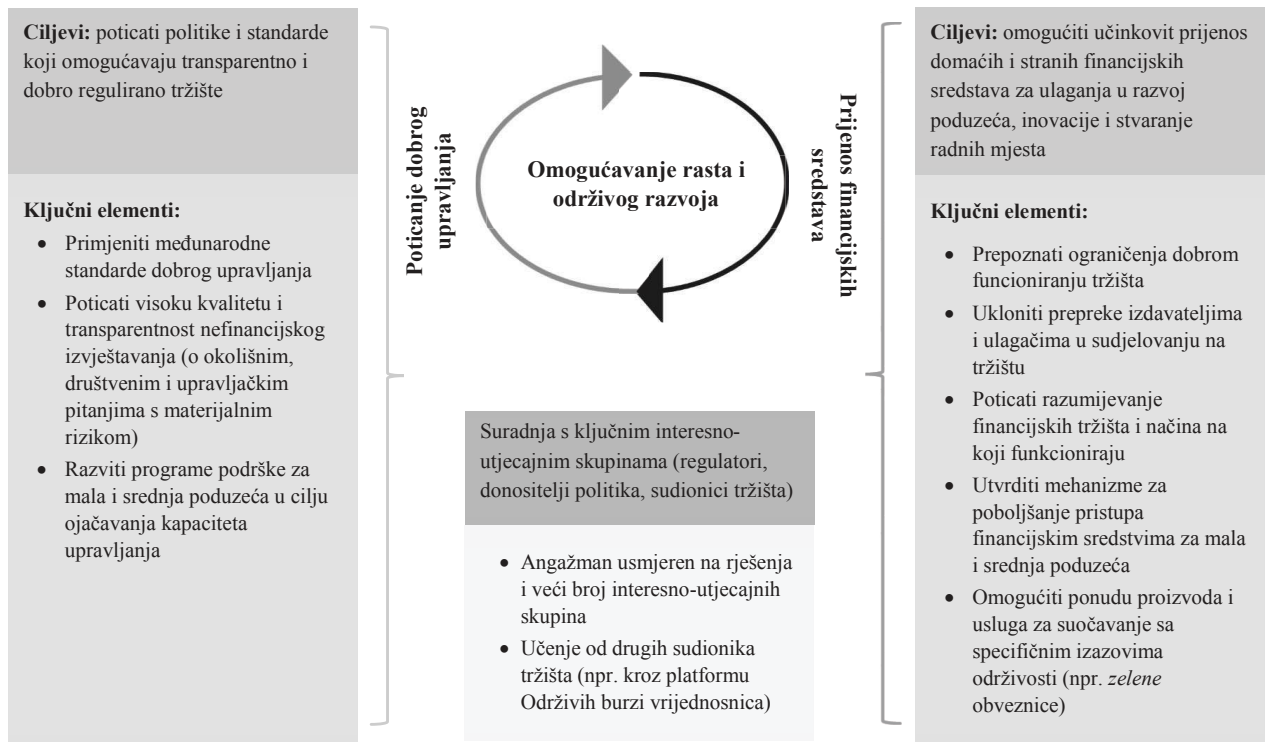

Slika 3. Uloge i aktivnosti održivih burzi vrijednosnica

Izvor: UNCTAD i World Federation of Exchanges (2017.).

Odluka o tome hoće li i kojim intenzitetom pojedina burza vrijednosnica obavljati određene aktivnosti vezane uz poticanje održivosti na financijskim tržištima, najčešće ovisi o njima samima, tj. predstavlja strateško opredjeljenje njihova menadžmenta. Primjerice, $\mathrm{s}$ obzirom da je nefinancijsko izvještavanje uglavnom dobrovoljno, neke burze vrijednosnica uvele su takav oblik izvještavanja kao dio pravila za izdavatelje vrijednosnih papira. U nekim slučajevima to je bio zahtjev regulatora (npr. Komisija za vrijednosnice i burzu u Indiji) a ponekad je bio i zahtjev same burze (npr. Hongkongška burza). No postoje i burze vrijednosnica koje još uvijek ne zahtijevaju od izdavatelja takvu vrstu izvještavanja.

\section{KVALITATIVNA ANALIZA POSLOVNOG SLUČAJA POTICANJA ODRŽIVIH I ODGOVORNIH FINANCIJSKIH ULAGANJA}

\subsection{Uzorak i metodologija istraživanja}

Teorijski pregled koncepta i uloge održivih burzi vrijednosnica, uzimajući u obzir i prikaz njihove prakse, poželjno je i potrebno proširiti dubinskom analizom primjera uspješne održive burze vrijednosnica. U nastavku je prikazana dobra praksa grupe Deutsche Boerse, jedne od najvećih svjetskih pružatelja tržišne infrastrukture i u segmentu tradicionalnih i u segmentu održivih i odgovornih financijskih ulaganja (primjerice, prema UNEP, 2017.). Deutsche Boerse ima treći najveći postotak zelenih prihoda od uvrštenja među burzama vrijednosnica u skupini G7 zemalja. 
Kao međunarodna financijska institucija i inovativni pružatelj tržišne infrastrukture, grupa Deutsche Boerse nudi širok spektar proizvoda, usluga i tehnologija čime pokriva cijeli lanac vrijednosti financijskih tržišta (Deutsche Boerse Group, 2019a.). Područje poslovanja kreće se od pripreme i kotacije vrijednosnih papira na tržištu, trgovanja, kliringa i namire do skrbničkih usluga za vrijednosne papire i druge financijske instrumente zajedno s upravljanjem kolateralom i likvidnošću. Osim toga, Grupa pruža IT usluge, indekse i tržišne podatke širom svijeta (Deutsche Boerse Group, 2019a.).

Grupa Deutsche Boerse neprekidno surađuje s velikim brojem različitih interesno-utjecajnih skupina, čija se važnost procjenjuje na temelju internih istraživanja. Ovisno o točki gledišta, bilo da se Deutsche Boerse promatra kao organizator tržišta kapitala ili kao izdavatelj, vrste i interesi tih skupina mogu biti različiti. Ključne interesno-utjecajne skupine i njihovi međuodnosi prema Deutsche Boerse prikazani su na slici 4.

$\begin{array}{lll}\begin{array}{l}\text { Grupa Deutsche Boerse } \\ \text { kao izdavatelj }\end{array} & \begin{array}{c}\text { Grupa Deutsche Boerse kao } \\ \text { organizator tržišta kapitala }\end{array} \\ \begin{array}{lll}\text { - Dioničari Deutsche Boerse } & & \\ \text { - Predstavnici zaposlenih } & \text { - Nadzorne institucije } & \text { - Posrednici } \\ \text { - Zaposleni } & \text { - Politika } & \text { - Izdavatelji } \\ \text { - Poslovni partneri } & \text { - Mediji } & \text { - Institucionalni/pojedi- } \\ \text { - Dobavljači } & \text { - Nevladine } & \text { načni ulagači } \\ \text { - Pružatelji usluga } & \text { organizacije } & \text { - Trgovanje, kliring i } \\ & \text { - Društvo } & \text { sudionici nakon prodaje } \\ & & \text { - Financijsko okruženje } \\ \hline\end{array}\end{array}$

Slika 4. Perspektiva interesno-utjecajnih skupina grupe Deutsche Borse

Izvor: Deutsche Boerse Group (2019b.). Stakeholders. Dostupno na: https://www.deutsche-boerse.com/dbg-en/ sustainability/materiality-analysis/stakeholders.

Dok su dioničari, zaposlenici i poslovni partneri prije svega zainteresirani za samo poduzeće, tj. za dobro upravljanje poduzećem i rezultate u dugom roku, klijenti - kao što su izdavatelji te sudionici trgovanja, kliringa i poslovanja nakon prodaje - fokusiraju se na sveobuhvatnu, učinkovitu i visokokvalitetnu ponudu proizvoda i usluga. Za nadzorne institucije, politiku i društvenu zajednicu, najvažnija uloga Deutsche Boerse je u njezinom doprinosu stabilnosti i učinkovitosti financijskih tržišta, u čemu se ogleda i njezina uloga u funkcioniranju njemačkog gospodarstva (Deutsche Boerse Group, 2019c.).

Istraživanje koje je obuhvatilo sustav podrške održivom financiranju od strane grupe Deutsche Boerse i njezinih poslovnih partnera te nastojalo prikazati ponudu i potražnju za razvojem financijskih proizvoda temeljenih na ESG kriterijima je provedeno u dvogodišnjem razdoblju od 2017. do 2018. godine. Primjenom metode dubinskog polustrukturiranog intervjua provedeni su razgovori s osobama na vodećim pozicijama unutar Odjela za održivi razvoj Deutsche Boerse (matična organizacija unutar grupe Deutsche Boerse) i Odjela za razvoj proizvoda STOXX (tvrtka kćer Deutsche Boerse) te analitičarem iz Odjela za istraživanje i analizu tvrtke Sustainalytics (rejting organizacije koja pruža analitičke usluge $\mathrm{s}$ fokusom na nefinancijsko poslovanje). 
Navedena kvalitativna metoda istraživanja odabrana je jer uključuje provođenje intenzivnih pojedinačnih razgovora s malim brojem ispitanika kako bi se istražili njihovi pogledi na pojedinu ideju, program ili situaciju (Boyce i Neale, 2016.). Takvim dizajnom istraživanja nastajalo se saznati koje aktivnosti Deutsche Boerse poduzima u području održivosti na financijskim tržištima. Dodatno, cilj rada bio je istražiti i perspektivu održivog financiranja te ulogu i odgovornost koju grupa Deutsche Boerse ima u stvaranju tržišta kapitala koje se ne fokusira isključivo na kratkoročne financijske prinose. Takva metodologija istraživanja u skladu je s deskriptivnom teorijom interesno-utjecajnih skupina, koja nastoji uzeti u obzir poglede sudionika o tome što organizacija radi u odnosu na svoje interesno-utjecajne skupine, kao i mehanizme kroz koje se oblikuju različita stajališta (Brickson, 2007.).

Priprema istraživanja sastojala se od istraživanja za stolom, tj. analize sadržaja javno dostupne dokumentacije o poslovnim načelima i aktivnostima grupe Deutsche Boerse kao što su godišnja izvješća, objave vezane uz aktivnosti i događanja, kao i proučavanje ostalih raspoloživih sekundarnih izvora podataka.

Proces izbora sudionika intervjua za prikupljanje primarnih podataka se temeljio na njihovoj relevantnosti i stručnosti vezano uz temu istraživanja. Intervjui su provedeni s tri ispitanika koji imaju veliko iskustvo u području održivosti na financijskim tržištima i koji dobro razumiju stanje na tržištu. Odobrenje za provođenje intervjua dobiveno je od strane menadžmenta grupe Deutsche Boerse. Dva ispitanika su na vodećim pozicijama u svojim odjelima, a treći ispitanik je istaknuti analitičar s dugogodišnjim iskustvom. Intervjui su provedeni licem u lice ili preko telefona. Prosječno trajanje intervjua bilo je oko 40 minuta.

Pitanja korištena u intervjuiranju voditeljice Odjela za održivi razvoj Deutsche Boerse grupirana su u tri skupine. Prva skupina pitanja se odnosila na tržište održivih i odgovornih financijskih ulaganja (njegov razvoj i značajke, trenutno stanje, izazove i očekivanja tržišnih kretanja). Druga je skupina pitanja bila vezana za ulogu financijskog sektora i posebice burzi vrijednosnica u poticanju održivog financiranja (mogućnosti i odgovornosti, pregled djelovanja). Trećom skupinom pitanja obuhvaćene su posebnosti grupe Deutsche Boerse u sustavu održivih i odgovornih financijskih ulaganja (konkretni razlozi ovakvog usmjerenja, poduzete aktivnosti, planirane aktivnosti).

U intervjuiranju voditelja Odjela za razvoj proizvoda - STOXX pitanja su bila grupirana u četiri skupine, prema područjima: tržište održivih i odgovornih financijskih ulaganja (sudionici, proizvodi, interes za nefinancijske informacije), ESG indeksi (pregled, mogućnosti korištenja, utjecaj na ulagače), organizacijski model STOXX-a u ESG segmentu poslovanja (organizacijska struktura, uloga pojedinih tijela, zaposlenici specijalizirani za ESG pitanja) i očekivanja razvoja tržišta u budućnosti (perspektivna područja održivih i odgovornih financijskih ulaganja, uloga STOXX-a u poticanju održivog financiranja na tržištima kapitala).

Pitanja korištena u intervjuiranju analitičara iz Odjela za istraživanje i analizu tvrtke Sustainalytics obuhvatila su sljedeća područja: tržište održivih i odgovornih financijskih ulaganja (ponuda usluga Sustainalytics-a, najvažniji kupci usluga, odnosi s drugim sudionicima tržišta), kriteriji održivih i odgovornih financijskih ulaganja (referentni dokumenti, upravljanje kriterijima, formalizacija i standardizacija radnih procedura, pitanje subjektivnosti procjena) i karakteristične strategije takvih ulaganja (tržišna potražnja za različitim strategijama ulaganja). 
Na osnovi analize dostupne dokumentacije grupe Deutsche Boerse i provedenih razgovora s njezinim djelatnicima odnosno partnerima, prepoznate su strateška i operativna razina poticanja održivih i odgovornih financijskih ulaganja.

\subsection{Strateška razina poticanja održivih i odgovornih financijskih ulaganja na primjeru grupe Deutsche Boerse}

Poticaje za razvoj održivog financiranja moguće je uvesti na različitim razinama institucije. U slučaju grupe Deutsche Boerse, tri poticaja prepoznata su kao strateški važna: (1) kreiranje upravljačkog tijela za održivo poslovanje, (2) pokretanje i/ili aktivno sudjelovanje u inicijativama razvoja održivog financiranja i (3) pokretanje platforme za zelene obveznice.

Održivi razvoj financijskog sustava temelji se na održivom razvoju njegovih pojedinih sudionika. Stoga ne iznenađuje osviještenost i strateško opredjeljenje menadžmenta grupe Deutsche Boerse o važnosti održivog poslovanja za njihov uspjeh. Kao bi se maksimalno iskoristio potencijal profila vlastite održivosti, grupa Deutsche Boerse osnovala je u 2016. upravljačko tijelo za održivo poslovanje radi razvoja strategije održivosti za cijelu Grupu i savjetovanja izvršnog odbora o pitanjima vezanima za održivost. Upravljačko tijelo sastaje se dva puta godišnje, a njegovi članovi obuhvaćaju po tri predstavnika svakog odjela te voditelja tijela (United Nations Global Compact, 2018.).

Strateški angažman grupe Deutsche Boerse ostvarivanju ciljeva održivog financiranja vidljiv je i kroz nekolicinu inicijativa pokrenutih samostalno ili u suradnji s partnerskim organizacijama. Od 2011. godine grupa Deutsche Boerse potiče primjenu njemačkog kodeksa održivosti, koji predstavlja standard za izvještavanje u ovom području (UNEP, 2017.).

U 2017. godini u Frankfurtu pokrenuta je nova Inicijativa ubrzavanja održivog financiranja koja predstavlja platformu za okupljanje ključnih sudionika financijskog centra (obuhvaćajući financijske institucije i predstavnike iz akademske zajednice i nevladinih organizacija) kako bi se poticalo održivo financiranje (UNEP, 2017.). Sudjelovanje na dobrovoljnoj bazi ima za cilj aktivan zajednički rad na temelju vlastite poslovne djelatnosti, prema mobilizaciji infrastrukture održivog financijskog tržišta i primjene svjetskih ciljeva u području održivosti (npr. UN-ovih Ciljeva održivog razvoja, Pariškog sporazuma o klimatskim promjenama te također fokusa na zeleno financiranje njemačkog predsjedavanja zemljama G20).

Krajem 2017. u suradnji s Ministarstvom gospodarstva savezne pokrajine Hessen osnovan je i Njemački klaster zelenog i održivog financiranja (The Green and Sustainable Finance Cluster Germany e.V. - GSFCG). Njegov cilj je daljnja mobilizacija financijskog sektora u svrhu zaštite od klimatskih promjena i u svrhu održivog financiranja. Klaster kao udruženje se temelji na širokoj podršci financijske zajednice (United Nations Global Compact, 2018.). Kao jedan od zadataka klastera definirana je i objava godišnjih izvještaja o aktivnostima u području održivosti financijskog centra u Frankfurtu, čime će se dodatno povećati transparentnost i prisutnost teme održivog financiranja.

Grupa Deutsche Boerse je ,razvila suradnju i s drugim burzama vrijednosnica kroz razne projekte, inicijative i svjetska udruženja kao što su Održive burze vrijednosnica, radna grupa za održivi razvoj UN-a te Svjetsko udruženje burzi vrijednosnica“. Pritom, ,,interes grupe Deutsche Boerse nije biti različit od svojih konkurenata po ovom pitanju, već se 
s njima uskladiti kako bi bolje učili i razmjenjivali iskustva jedni od drugih. Svaka burza vrijednosnica ima svoje tržište i priliku za primjenjivanje sličnih projekata na različite načine, no harmonizacija i usklađenost između burzi potrebni su kako bi se koncept održivog financiranja dalje uspješno razvijao.“

Postoje i različiti pokreti i inicijative s obzirom na različite strukture financijskih sektora. „Fokus financijskog centra u Londonu, Parizu ili Luksemburgu je na zelenom financiranju i stvaranju zelenog segmenta tržišta obveznica." Slično razmišlja i grupa Deutsche Boerse, što je 2018. godine rezultiralo pokretanjem platforme za zelene obveznice u Frankfurtu, koja uključuje oko 150 obveznica, usklađenih s Načelima zelenih obveznica Međunarodnog udruženja tržišta kapitala (United Nations Global Compact, 2018.). Predstavnici grupe Deutsche Boerse ovdje naglašavaju kako „,ne žele doprinositi održivom razvoju isključivo kroz prizmu zaštite prirodnog okoliša, već kroz sve segmente održivosti. Kroz sveobuhvatno djelovanje postiže se održivi razvoj društva, korporativnog upravljanja, a i zaštite prirodnog okoliša.“

\subsection{Operativna razina poticanja održivih i odgovornih financijskih ulaganja na primjeru grupe Deutsche Boerse}

Uz strateške poticaje, jednako su važni poticaji za razvoj održivog financiranja na operativnoj razini. U slučaju grupe Deutsche Boerse, radi se o sljedećem: (1) kreiranje operativnih grupa za održivi razvoj, (2) suradnja s pružateljima usluge ESG analitike, (3) inicijative poticanja transparentnosti, (4) razvoj proizvoda i usluga održivog financiranja te (5) provođenje interne ankete među interesno-utjecajnim skupinama.

„U posljednjih nekoliko godina osnovane su tri operativne grupe s fokusom na proizvode i usluge, strategije i budućnost nefinancijskih (ESG) informacija.“ Na taj način grupa Deutsche Boerse „ojačava svoju poziciju pružatelja infrastrukture tržišta kapitala, ali i osigurava bolje upravljanje vlastitim poslovnim sustavom“. „Odjel održivog razvoja Deutsche Boerse već nekoliko godina prati napredak tržišta održivih i odgovornih financijskih ulaganja i važnost nefinancijskih informacija, imajući u vidu da je osnovna djelatnost Deutsche Boerse pružanje tržišne infrastrukture i omogućavanje transparentnog, sigurnog i stabilnog tržišta kapitala.“ Specifično, ,zaposlenici Odjela prate u kojoj je mjeri poslovanje izdavatelja na Deutsche Boerse i poduzeća s kojima burza surađuje održivo. Na taj način, procjenjuju sve rizike i prilike koje proizlaze iz okolišnih, društvenih i upravljačkih pitanja, ali i upravljaju lancem vrijednosti listiranih poduzeća“. Stvaranjem smjernica najbolje prakse za primjenu nefinancijskih informacija te neprekidnim educiranjem tržišnih sudionika kroz webinare (izlaganja koja se prate preko interneta u stvarnom vremenu) i seminare podiže se svijest o održivim i odgovornim financijskim ulaganjima. Na webinarima se najviše nastoje educirati privatni ulagači o općenitim načelima i raspoloživim strategijama održivih i odgovornih financijskih ulaganja. Nažalost, ,postoji nedostatak razumijevanja o tome što znači biti ulagač u održivi razvoj. Iz tog razloga okolišna, društva i upravljačka pitanja nastoje se predstaviti kao dodatna dimenzija poslovanja, a ne kao prisila regulatora ili trenutni trend.“

Važan doprinos realizaciji postavljenih ciljeva vezanih uz održivo financiranje pruža i suradnja grupe Deutsche Boerse s rejting organizacijama usredotočenim na nefinancijske informacije. Partnerska organizacija Sustainalytics je samostalno poduzeće koje, kao svoje 
temeljne usluge, pruža usluge istraživanja okolišnih, društvenih i upravljačkih pitanja u poslovanju te usluge analize i dodjeljivanja ESG rejtinga (ocjena). Time pruža podršku ulagačima širom svijeta. Od strane ulagača Sustainalytics je tri godine zaredom (2012. - 2014.) izabran kao najbolje samostalno poduzeće u području istraživanja održivih i odgovornih financijskih ulaganja, a u 2015. godini imenovan je među tri najbolja poduzeća u ESG analitici (Vezer et al., 2017.).

Sustainalytics prikuplja podatke i analizira održivost poduzeća listiranih na burzi vrijednosnica s obzirom na ESG kriterije. Prikupljeni podaci omogućuju grupi Deutsche Boerse kreiranje tržišnih indeksa održivosti. Sustainalytics, ,na temelju ESG istraživanja i analize, nudi mišljenje utemeljeno na podacima,“ čime je subjektivna procjena analitičara Sustainalytics-a svedena na minimum. „Za primjer, procjena možebitne diskriminacijske politike u poduzeću se donosi na temelju standarda Međunarodne organizacije rada. Pri procjeni društvene odgovornosti poduzeća analitičar će istražiti kako njegov menadžment upravlja tim rizikom uzimajući u obzir pitanja poput visine minimalne plaće, prihvatljivih radnih uvjeta itd. Kad je riječ o korupciji, kao referentni dokument koriste se UN-ova Načela Global Compact, a kod pitanja održivih i odgovornih financijskih ulaganja UN-ova Načela odgovornih ulaganja. Nakon korištenja dokumenata relevantnih za temu, analitičar Sustainalytics-a dalje provjerava ostale javno dostupne informacije (npr. izvješća o društveno odgovornom poslovanju, izvješća o održivosti, etičke kodekse i sl.) kako bi mogao što kvalitetnije ocijeniti poslovanje poduzeća u području okolišnih, društvenih i upravljačkih pitanja i ponuditi objašnjenje za danu procjenu analiziranog poduzeća.“

„Ulagači koji žele integrirati nefinancijske informacije u svoje investicijske procese plaćanjem pretplate dobivaju pristup Sustainalytics-ovoj bazi ESG istraživanja i rejtinga. Poduzećima Sustainalytics ne naplaćuje dodjelu rejtinga“, čime je u velikoj mjeri izbjegnut sukob interesa.

Grupa Deutsche Boerse razvila je i nekoliko inicijativa u cilju povećanja transparentnosti i učinkovitosti u području nefinancijskih (ESG) informacija i održivih i odgovornih financijskih ulaganja. Kroz inicijative transparentnosti, sva poduzeća uključena u tržišne indekse DAX, MDAX, SDAX i TechDAX objavljuju nefinancijske informacije (UNEP, 2017.). Fokusiranjem na standardizaciju ESG informacija ubrzan je kapacitet izdavatelja u sustavnom razvoju i primjeni strategija održivosti (UNEP, 2017.). Što se tiče prakse vlastitog izvještavanja, Grupa od 2012. godine objavljuje kombinirano godišnje izvješcee, koje uključuje i informacije iz tradicionalnih financijskih izvještaja i detalje o održivom poslovanju poduzeća. Posljednji izvještaji napravljeni su u skladu sa standardima Globalne inicijative za izvještavanje (GRI). Specifično, kao dio godišnjeg izvještaja objavljen je indeks GRI koji obuhvaća osnovne pokazatelje održivosti kao i odgovarajuće opise.

Jedan od ključnih poticaja za održiva i odgovorna financijska ulaganja predstavlja raspoloživost proizvoda i usluga održivog financiranja. „Održivi financijski proizvodi i usluge su oni proizvodi i usluge koji, osim što pokušavaju ostvariti financijsku korist, također pokušavaju kreirati i nefinancijsku korist imajući u vidu okolišne, društvene i upravljačke kriterije.“ Za ovaj segment poslovanja u sklopu Deutsche Boerse postoji tim od troje zaposlenih, a važnu ulogu ima i STOXX, tvrtka kćer Deutsche Boerse koja pruža usluge razvoja indeksa i ostalih financijskih proizvoda/usluga na temelju zahtjeva klijenata. Održivi indeksi razvijeni su kako bi se ulagačima ponudile mogućnosti održivih i odgovornih financijskih ulaganja. Putem STOXX-a, Deutsche Boerse računa i nudi više od 11.000 indeksa, među 
kojima je sve veći broj oblikovan uzimajući u obzir aspekte održivosti (United Nations Global Compact, 2018.). Pri razvoju indeksa, Odjel razvoja proizvoda STOXX-a koristi podatke koje im je omogućio Sustainalytics. Burza nudi 35 različitih indeksa održivosti i sveobuhvatan skup ESG pokazatelja u svrhu objave informacija (UNEP, 2017.). Primjerice, najnoviji indeks u grupi STOXX-ovih ESG indeksa predstavljen krajem 2018. godine kao STOXX ESG-X indeks temelji se na STOXX® Europe 600 indeksu, jednom od europskih mjerila vrijednosti, s primijenjenim standardiziranim ESG kriterijima isključenja (United Nations Global Compact, 2018.). „Ipak, unatoč sve većem interesu za razvojem novih, održivih financijskih proizvoda/usluga, značajniji broj zaposlenika STOXX-a još uvijek radi u prodajnom odjelu, dok je za razvoj proizvoda zadužena tek svaka deseta osoba.“

Konačno, korisna je i interna inicijativa anketiranja interesno-utjecajnih skupina grupe Deutsche Boerse, pokrenuta prije nekoliko godina s ciljem proširenja i intenziviranja dijaloga i suradnje s različitim interesno-utjecajnim skupinama.

\subsection{Perspektive razvoja održivih i odgovornih financijskih ulaganja}

Deskriptivnu teoriju interesno-utjecajnih skupina, korištenu pri analizi poslovnog slučaja grupe Deutsche Boerse, moguće je nadopuniti s instrumentalnom teorijom interesno-utjecajnih skupina. Glavna razlika između ta dva pristupa je što se deskriptivna teorija bavi pitanjima kakav svijet je i ponekad objašnjava specifične karakteristike poduzeća i njegovog ponašanja, dok se, s druge strane, instrumentalna teorija bavi pitanjima kakav bi svijet trebao biti, tumači funkciju i nudi smjernice budućeg razvoja (Donaldson i Preston, 1995.). Kako bi se sagledao daljnji razvoj održivih i odgovornih financijskih ulaganja, uzete su u obzir perspektive različitih interesno-utjecajnih skupina: Deutsche Boerse, STOXX-a i Sustainalytics-a.

Iz perspektive Deutsche Boerse, konkretno njezina Odjela za održivi razvoj, ,postoje različiti izazovi s kojima se burze vrijednosnica susreću i isključiv fokus na samo jedan segment održivog financiranja neće donijeti transformaciju tržišta kakva se priželjkuje“. Primjerice, prema stajalištu ispitanika, ,uvođenje nove platforme za zelene obveznice nije dovoljno, već je potrebno pozeleniti tradicionalne strukture tržišta kapitala odnosno cijeli segment tržišta obveznica“.

Međutim, ESG pitanja na financijskom tržištu trenutno imaju sekundaran značaj. Prema istraživanjima koje provodi Deutsche Boerse, „osnovna zapreka snažnijem razvoju održivih i odgovornih financijskih ulaganja je činjenica da je fokus suvremenih financijskih tržišta na kratkoročnim ulaganjima utemeljenima na riziku“. Takvo viđenje potvrđeno je i kroz razgovor sa specijalistima iz banaka, koji ,financijske proizvode poput zelenih obveznica smatraju trendom za privlačenje ulagača i postizanje većeg ugleda na tržištu. Primarni cilj je financijska dobit, stoga se nefinancijskim kriterijima pridaje relativno malen značaj. Potrebna je određena promjena načina razmišljanja, koja bi obuhvatila sve strukture tržišta kapitala, kroz posebne projekte koji se nadograđuju na tradicionalnu strukturu financijskog sustava. Burza vrijednosnica tu predstavlja prikladnog sudionika tržišta koji nudi platformu za suradnju i utvrđuje konkretna područja za aktivnosti u smjeru održivosti financijskih tržišta.“

Deutsche Boerse naglašava i „,važnost postizanja određene razine razmišljanja od strane samih poduzeća, na kojoj će iz njihove perspektive održivo poslovanje biti poslovna 
logika i način na koji se postiže status kvalitetnog sudionika tržišta, poželjnog objekta ulaganja, poželjnog poslodavca itd. Iz tog razloga, a polazeći od stava da je odgovornost i burze vrijednosnica educirati sudionike tržišta o održivim i odgovornim financijskim ulaganjima, Deutsche Boerse nudi edukaciju poduzećima. Iako sami sudionici tržišta mogu imati značajan utjecaj na tržište, za postizanje razine njihove samoregulacije trebat će dosta vremena, stoga je, uz samoregulaciju, naglašena važnost i potreba i za učinkovitom regulativom, prilagođenoj obilježjima tržišta.“

Odjel za održivi razvoj zalaže se za to da je „odgovornost svih burzi vrijednosnica, ne samo Deutsche Boerse, osiguranje transparentnog, stabilnog i otpornog tržišta. Globalna financijska kriza od 2007./2008. godine pokazala je kako takvo tržište nije moguće postići donoseći odluke isključivo na temelju financijskih pokazatelja subjekata u koje se ulaže, jer oni ne mogu jamčiti ovu vrstu stabilnosti i otpornosti na tržištima. Iz tog je razloga moguće da će biti potrebne dodatne, nefinancijske informacije, koje zajedno s financijskim, ključnim pokazateljima poslovanja omogućuju ulagačima bolje upravljanje svim povezanim rizicima i prilikama.“

Povećanje održivosti na financijskim tržištima ispitanici vide kao „sastavni dio osnovne djelatnosti, a ne kao dodatnu dimenziju poslovanja. Sve burze vrijednosnica trebale bi težiti ostvarivanju financijskih prinosa na način na koji niti jedna interesno-utjecajna skupina nije oštećena te koji donosi korist za što veći broj tih skupina. Takvo ostvarivanje financijskih prinosa smatraju situacijom u kojoj su sve strane na dobitku. Isključiv fokus na kratkoročan profit nije smisao održivog poslovanja. Burze vrijednosnica su u poziciji da imaju priliku educirati sudionike financijskog tržišta (posebno upravljače imovinom i menadžere poduzeća uvrštenih na burzu vrijednosnica) o održivosti financijskog tržišta."

Prema voditeljici Odjela održivog razvoja, ,,postoje promjene koje se mogu napraviti sa strane burzi vrijednosnica. Početni korak u tome je uspostavljanje platforme za dijalog o budućnosti tržišta i za suradnju između različitih interesno-utjecajnih skupina koje, uz burzu vrijednosnica, obuhvaćaju i izdavatelje, ulagače, regulatore, političare i dr. Deutsche Boerse je taj korak napravila Inicijativom održivih financija, u sklopu koje je oformila tri radne skupine. Jedna radna skupina je zadužena za razvoj proizvoda i usluga, druga za nove strategije ulaganja, a trećoj je fokus na budućnosti ESG informacija.“

„Sljedeći korak, nakon uspostavljanja takve platforme, bio bi utvrđivanje područja konkretnih aktivnosti. Neke od njih su proširenje portfelja proizvoda i usluga burze vrijednosnica, moguće postavljanje ESG kriterija kao kriterija za uvrštenje na burzu vrijednosnica, poticanje regulatora na učinkovitija pravila u ovom području, analiza pitanja poreza na ugljik i trgovanja emisijskim jedinicama plinova u Europi, postavljanje kriterija veće transparentnosti poduzeća o okolišnom riziku vezanom za klimatske promjene. Za razvoj ovakvog sustava bit će potrebno vrijeme." Prema mišljenju voditeljice Odjela za održivi razvoj, ,najmanje tri do pet godina, kako bi interesno-utjecajne skupine razumjele što bi se moglo postići takvim sustavom. Iz tog razloga cilj nije prisiljavanje ulagača regulacijom na primjenu ESG kriterija u donošenju investicijskih odluka, već razumijevanje da je dobro upravljanje takvim kriterijima važno za smanjenje nefinancijskih rizika koji se u budućnosti mogu materijalizirati, kao i za otvaranje novih inovativnih područja poslovanja. Ukoliko se dostigne ta razina primjene ESG kriterija u poslovanju odnosno korištenja nefinancijskih informacija u investicijskom procesu, poduzeća će biti motivirana spomenutom poslovnom logikom, a ne prisilom ili isključivo etikom.“ 
U STOXX-u, zaduženom za razvoj indeksa, je ,razvoj nove vrste tržišnih indeksa bio motiviran sve većim potencijalom financijskih proizvoda temeljenih na ESG čimbenicima, koji je vidljiv posebno u posljednjih nekoliko godina. U 2010. godini STOXX je nudio 10 takvih indeksa, a do danas se njihov broj povećao na 80.“ Iako je navedeno prema STOXX-u ,pokazatelj rastućeg trenda važnosti održivosti na financijskom tržištu“, stajalište predstavnika Odjela održivosti naglašava kako „ta statistika nije dovoljna“.

ESG indeksi se koriste u različite svrhe. „U najvećoj mjeri služe za usporedbu. Ulagači ih koriste kako bi mogli učinkovito usporediti svoj portfelj s okolišnim, društvenim i upravljačkim zahtjevima.“ Primjerice, vrijednost imovine kojom se upravlja u sklopu ETF fondova (engl. exchange traded fund) čijim se dionicama trguje na burzi, a koji prate ESG indekse, sedmerostruko je povećana u posljednjih nekoliko godina (od 12,4 milijuna EUR u 2016., na 91,9 milijun EUR u 2018. godini).

„Postoji i širok spektar deriviranih financijskih instrumenata na temelju ESG indeksa koje nude različiti institucionalni investitori.“ Kao druga raširena svrha korištenja ESG indeksa navedeno je ,živičenje (engl. hedging), koje ulagači koriste kako bi uravnotežili svoj portfelj pomoću financijskih proizvoda temeljenih na okolišnim, društvenim i upravljačkim čimbenicima i zaštitili ga od nepovoljnih ishoda.“ Kao primjer ovakve prakse spomenut je „veliki klijent iz Skandinavije koji je želio svoje poslovanje uskladiti s ciljem smanjivanja korištenja ugljena kao energenta.“ Usklađivanje je u tom smislu značilo stvaranje portfelja sastavljenog od vrijednosnica isključivo onih poduzeća koja imaju politiku korištenja niske razine ugljena. ,Klijent je pritom uzeo indeks STOXX kao mjerilo vrijednosti te je temeljio svoje investicijske odluke prema tom indeksu.“

„Aktualan trend na tržištu održivih i odgovornih financijskih ulaganja je da se imovinom u sve većoj mjeri upravlja na pasivan način odnosno da se nefinancijske informacije primjenjuju pasivno. Pritom je cilj stvaranje portfelja koji prati neki tržišni ESG indeks, a indeks predstavlja temelj za investicijske odluke. Suprotno tome, u prošlosti se imovinom češće upravljalo na način da se razradi strategija ulaganja, upravlja na temelju i financijskih i nefinancijskih informacija, pri čemu bi nefinancijske informacije služile kao orijentir, ali ne i presudan čimbenik za investicijske odluke, a portfelj bi se uspoređivao s ESG indeksom u funkciji mjerila vrijednosti.“ Predstavnici STOXX-a „među ponudom ESG indeksa najveći potencijal vide u indeksima povezanima s temom klimatskih promjena, posebno nakon potpisivanja Pariškog sporazuma (2015.). S obzirom na činjenicu da klimatske promjene predstavljaju sve veći izazov, ovo su najperspektivniji i najviše korišteni ESG indeksi.“

Predstavnici STOXX-a navode da su ,ulagači u tržišnom segmentu održivih i odgovornih financijskih ulaganja najvećim dijelom institucionalni, prije svega mirovinski fondovi i osiguravateljna društva, s dugoročnim investicijskim horizontom i integriranom strategijom ESG. Pritom, korisnici usluga od STOXX-a zahtijevaju uzimanje u obzir ESG kriterija, ali s obzirom da su klijenti Deutsche Boerse primarno financijske institucije, oni za jasan cilj imaju ostvarivanje financijskog prinosa." Stoga STOXX u ovom području djelatnosti „svoju ulogu vidi u ponudi proizvoda koji primarno postižu financijske ciljeve, a onda i nefinancijske“"

Prema mišljenju predstavnika STOXX-a, ,Deutsche Boerse će biti važan sudionik na tržištu održivih i odgovornih financijskih ulaganja. S tržištem se treba uskladiti, ali potrebno je i utvrditi i tržišne prilike i poteškoće.“ Pritom ističu činjenicu da „ESG kriteriji nisu 
standardizirani i da nemaju sve zemlje istu percepciju o tome što je „dobro“, a što „loše“““ Kao primjer navode „različito stajalište Francuske i Njemačke o nuklearnoj energiji. Takve činjenice otežavaju usklađivanje na međunarodnoj razini.“

Ističu kako, ,usprkos istraživanjima koja pokazuju da financijski proizvodi temeljeni na okolišnim, društvenim i upravljačkim čimbenicima mogu imati jednako dobar financijski rezultat kao i tradicionalni financijski proizvodi koji se zasnivaju isključivo na financijskim pokazateljima te da je uzimanje u obzir nefinancijskih informacija u financijskim odlukama kvantificirano racionalno ponašanje, na tržištu su još uvijek dominantna ulaganja u instrumente s kratkoročnim prinosima."

Sustainalytics navodi kako se „u njihovoj organizaciji zbog promjena tržišnih trendova kao i regulatornih okvira, posebna pozornost posvećuje razvoju ESG kriterija. O ESG kriterijima se kontinuirano raspravlja i na taj način se njima i upravlja - interni tim Sustainalytics-a sastaje se dvomjesečno i sukladno potrebama, zbog navedenih razloga, obnavlja ESG kriterije.“”

„Materijalni rizik povezan s nefinancijskim pitanjima (financijska značajnost nefinancijskih pitanja), kao najtraženiji pristup održivim i odgovornim ulaganjima na financijskim tržištima“, ističe i Sustainalytics. S obzirom da je riječ o riziku koji proizlazi iz mogućeg negativnog materijalnog utjecaja nefinancijskih pitanja - okolišnih, društvenih i upravljačkih - na financijske kategorije uspješnosti poslovanja organizacije, taj je rizik posebno važan ulagačima. „Danas klijenti žele znati koji se materijalni rizik veže uz ESG pitanja odnosno kako ta pitanja utječu na pokazatelje financijske uspješnosti kao što su prihodi, vrijednost imovine itd.“ Među drugim važnim pristupima naglašavaju „utjecaj ulaganja na prirodni okoliš, društvo i upravljanje. Klijenti žele znati koji je „stvaran“ nefinancijski utjecaj održivih i odgovornih financijskih proizvoda, kao primjerice, zelenih obveznica i obveznica s društvenim utjecajem, za koje postoji velik interes ulagača, kao i npr. ulaganja u obnovljive izvore energije ili temu financijske uključenosti. Drugi rašireni pristupi održivim i odgovornim financijskim ulaganjima obuhvaćaju isključenje poduzeća, sektora ili zemalja iz prihvatljivog skupa ulaganja ako su povezani s određenim aktivnostima (primjerice, $s$ industrijom palminog ulja u Indoneziji sa značajnim negativnim utjecajem na okoliš), $E S G$ integraciju (primjena okolišnih, društvenih i upravljačkih rizika i prilika u procesu tradicionalne financijske analize, od samog početka do kraja investicijskog procesa) i strategiju angažmana (podrazumijeva aktivnu komunikaciju ulagača s poduzećima iz svog portfelja, izravnu ili sudjelovanjem na godišnjoj skupštini dioničara, podnošenjem rezolucija o nefinancijskim pitanjima kao što su klimatske promjene i sl., čime ulagač može utjecati na društveno odgovorno poslovanje tih poduzeća).“

Među svojim najvažnijim klijentima Sustainalytics navodi „,lasnike imovine (mirovinske fondove i državne organizacije odnosno državne imovinske fondove i općine), upravljače imovinom (najviše banke, ali i klijente u domeni privatnog kapitala), neprofitne organizacije i zaklade (npr. nevladine organizacije), koje žele biti sigurne da u svom portfelju ne drže vrijednosne papire poduzeća čije aktivnosti su kontradiktorne njihovoj misiji i poduzeća (npr. poduzeća koja pri izdavanju zelenih obveznica traže od Sustainalytics-a drugo mišljenje).“ 


\section{RASPRAVA}

\subsection{Teorijske implikacije istraživanja}

Ulogu i važnost burzi vrijednosnica u poticanju održivih i odgovornih financijskih ulaganja potrebno je i moguće promatrati primjenom stakeholderskog pristupa (Freeman, 1984.). Ovo istraživanje, iako stavlja naglasak na aktivnosti odabrane interesno-utjecajne skupine, polazi od pretpostavke da su različite interesno-utjecajne skupine jednako važne (Wagemans et al., 2013.). Inicijalna pretpostavka u sustavu promatrane burze vrijednosnica je potvrđena, jer je na osnovi prikupljenih primarnih i sekundarnih podataka moguće zaključiti kako Deutsche Boerse nastoji ostvariti svoje ciljeve kroz interakciju i suradnju s drugim interesno-utjecajnim skupinama, uključujući organizaciju Sustainalytics, gospodarske subjekte, ulagače, zaposlenike i dr.. Promatrani poslovni slučaj predstavlja jedno od prvih istraživanja u području održivog financiranja koje opisuje i ističe suradnju između različitih interesno-utjecajnih skupina (npr. Desai, 2018.) usmjerenu prema održivom financiranju.

Burze vrijednosnica, kao tradicionalno važan sudionik u stvaranju učinkovitih financijskih tržišta, surađuju s poduzećima koja posluju transparentno i kojima se dobro upravlja. Danas burze vrijednosnica imaju mogućnost poticati i pomagati poduzećima pri usvajanju najboljih praksi društveno odgovornog poslovanja (v. UNCTAD i World Federation of Exchanges, 2017.), što prikazuju i rezultati provedenih dubinskih intervjua u ovom istraživanju.

Na burzama vrijednosnica je i dio odgovornosti za postavljanje standarda koji bi povećali osviještenost o održivom financiranju. Na taj način burze vrijednosnica bi dale svoj doprinos rješavanju pitanja održivosti i dugoročno stabilnih financijskih tržišta (v. Cleary, 2015.). Sukladno tome, u radu je izložen i analiziran primjer financijske institucije koja je na strateškoj i operativnoj razini počela poticati održiva i odgovorna financijska ulaganja. Slično Planu aktivnosti svjetske Inicijative održivih burzi vrijednosnica (Sustainable Stock Exchanges Initiative, 2017.), rezultati dubinskih intervjua pokazali su da burza vrijednosnica može imati ulogu u akreditaciji određenih standarda koji pomažu daljnjem razvoju održivih financijskih proizvoda ili primjeni ESG rejtinga ili mjerila vrijednosti na tržištima. Deutsche Boerse suradnjom sa Sustainalytics otvara širokom krugu zainteresiranih ulagača mogućnost korištenja ESG rejtinga pri donošenju investicijskih odluka.

\subsection{Praktične implikacije istraživanja}

Rezultati dobiveni istraživanjem naglasili su različite perspektive pojedinih organizacija unutar grupe Deutsche Boerse. Te se perspektive u praksi odražavaju kao razilaženje između onoga što ulagači na tržištu traže i osviještenosti o okolišnim i društvenim problemima, koji se budućnosti neće moći riješiti bez pravodobnog integriranja i na financijskim tržištima. Dok Odjel za razvoj proizvoda u STOXX-u ističe kratkoročne prinose kao cilj ulagača, Odjel održivosti Deutsche Boerse zalaže se za financijska ulaganja kojima to nije isključiva motivacija.

Kako bi se uspostavili odgovarajući ESG standardi na burzi vrijednosnica bit će potrebno značajno vrijeme i trud i iz razloga što financijske institucije trebaju ponovno steći povjerenje svojih klijenata koje je izgubljeno tijekom posljednje financijske krize od 
2007./2008. godine (v. Herzig i Moon, 2013.). Stoga prije nego financijske institucije počnu pratiti društveno odgovorno poslovanje poduzeća i pružati informacije o takvom poslovanju ulagačima, nužno je postići odgovarajuću razinu održivog i odgovornog poslovanja i s vlastite strane. Dodatno, prema stajalištima intervjuiranih ispitanika, navedena kriza je pokazala i da burze vrijednosnica ne mogu postići svoju temeljnu aktivnost - pružanje transparentnog, stabilnog i sigurnog tržišta - fokusirajući se isključivo na pokazatelje financijske uspješnosti, već su potrebne i dodatne, nefinancijske informacije.

Konačno, burza vrijednosnica koja posluje na održiv i odgovoran način može ostvarivati dodatne koristi za različite interesne skupine - klijente, područje u kojem je smještena, financijske institucije i financijske profesionalce. Takve burze klijentima pružaju ekonomične i sigurne financijske usluge koje im omogućuju jednostavan prijelaz na održivo financiranje na domaćem i međunarodnom tržištu. Održive burze vrijednosnica su povezane s područjem u kojem su smještene te kroz stručnost i inovativno poslovanje mogu pomoći ubrzanju prijelaza na održivi razvoj u lokalnim gradovima i regijama. U takvom okruženju mogu napredovati i financijske institucije, domaće i međunarodne, kojima održiva burza vrijednosnica nudi priliku za rast i stvaranje atraktivnih financijskih prinosa odgovaranjem na okolišni imperativ. Sa stajališta financijskih profesionalaca, održiva burza vrijednosnica je i sjajno mjesto ljudske interakcije - gdje velik broj profesionalaca ostvaruje svoju karijeru. Takva burza vrijednosnica razlikovala bi se po načinu na koji je financijskim profesionalcima omogućeno postizanje svrhe i ostvarenje ispunjenja u karijeri (v. UNEP, 2017.).

\subsection{Ograničenja istraživanja}

Predmetno istraživanje sadrži i potencijalna ograničenja. Kao prvo ograničenje, primijenjena kvalitativna metodologija dubinskih intervjua može rezultirati pristranošću ispitanika ili istraživača. Uslijed toga, tamo gdje je to bilo moguće, provedena je triangulacija podataka (zapisi provedenih intervjua su uspoređeni s postojećom javno dostupnom dokumentacijom). Kao drugo ograničenje, metoda dubinskog intervjua ne dopušta pretjerano generaliziranje s obzirom na činjenicu da je broj ispitanika relativno malen. Ipak, odabrani ispitanici su vrlo dobro upućeni, kako u aktivnosti koje se po pitanju održivog financiranja provode u Deutsche Boerse, tako i u globalne trendove u području održivih i odgovornih financija. Konačno, praksa održivih i odgovornih financijskih ulaganja vezana je i uz širi društveni, ekonomski, institucionalni i regulatorni okvir te stupanj razvijenosti pojedinog financijskog tržišta. Stoga određene prikazane prakse i zaključci koji su proizašli iz proučavanja tematike možda neće biti u potpunosti primjenjivi u nekom drugom kontekstu, u kojem ne postoje isti preduvjeti za razvoj takvog načina poslovanja burzi vrijednosnica.

\section{ZAKLJUČAK}

Održivost na financijskim tržištima je višeslojna tema, o kojoj se sve više raspravlja u znanstvenim i stručnim krugovima, a na čiju su važnost počela ukazivati i najviša politička tijela poput Europske komisije. S druge strane, financijski sektor trenutno ne uzima uvijek u obzir okolišna, društvena i upravljačka pitanja na odgovarajući način (European Commission, 2017.). Razvojem održivih i odgovornih financijskih ulaganja moguće je postići veću 
učinkovitost, donijeti inovaciju, povećati odgovornost i opseg ulaganja, pritom ostvarujući ekonomske, društvene i okolišne koristi. Burze vrijednosnica kao važni sudionici financijskog tržišta imaju priliku, u suradnji s regulatorima, danas kreirati održivo financijsko tržište koje će biti otporno na izazove budućnosti.

Ovo je istraživanje omogućilo bolje razumijevanje dobre prakse tržišta održivih i odgovornih financijskih ulaganja. U radu su prepoznate različite inicijative poticanja takvih ulaganja na strateškoj i operativnoj razini grupe Deutsche Boerse. Strateški važnima istaknuti su kreiranje upravljačkog tijela za održivo poslovanje, pokretanje i/ili aktivno sudjelovanje u inicijativama razvoja održivog financiranja i pokretanje platforme za zelene obveznice. Na operativnoj razini to su kreiranje operativnih grupa za održivi razvoj, suradnja s pružateljima usluge ESG analitike, inicijative poticanja transparentnosti, razvoj usluga održivog financiranja te provođenje interne ankete među interesno-utjecajnim skupinama. U prepoznatim inicijativama ogleda se uloga burze vrijednosnica u sustavu održivih i odgovornih financijskih ulaganja.

U budućim istraživanjima ove tematike bilo bi poželjno obuhvatiti praksu i drugih burzi vrijednosnica, prije svega onih koje sudjeluju u inicijativama za poticanje održivog financiranja. Dobiveni nalazi istraživanja mogli bi potencijalno služiti za usporednu analizu pa čak i meta-sintezu pojedinih kvalitativnih primjera, u cilju generalizacije zaključaka i izdvajanja uspješnih od neuspješnih praksi burzi vrijednosnica.

\section{LITERATURA}

1. Banga, J. (2019.). The green bond market: a potential source of climate finance for developing countries. Journal of Sustainable Finance \& Investment, 9(1), 17-32.

2. Baulkaran, V. (2019.). Stock market reaction to green bond issuance. Journal of Asset Management, 20(5), 331-340.

3. Boyce, C. i Neale, P. (2016.). Conducting in-depth interviews: A Guide for Designing and Conducting In-Depth Interviews for Evaluation Input. Pathfinder International.

4. Brickson, S. (2007.). Organizational Identity Orientation: The Genesis of the Role of the Firm and Distinct Forms of Social Value, Academy of Management Review, 32(3), 864-888.

5. Brzeszczysnki, J. i McIntosh, G. (2014.). Performance of Portfolios Composed of British SRI Stocks. Journal of Business Ethics, 120(3), 335-362.

6. Chesebrough, D., Feller, E., Grabski, T., Miller, A. i Paty, M. (2016.). Report on Progress. Sustainable Stock Exchanges Initiatives.

7. Chhichhia, B. (2015.). The Rise of Social Stock Exchanges. Stanford Social Innovation Review, Jan 8.

8. Cleary, S. (2015.). Stock exchanges and sustainability. Inquiry Working Paper 15/13. United Nations Environment Programme. Dostupno na http:/unepinquiry.org/ wp-content/uploads/2015/12/Stock_Exchanges_and_Sustainability.pdf.

9. Cunha, F.A.F. de S. i Samanez, C. P. (2014.). Performance analysis of sustainable investments in the Brazilian stock market, Production, 24(2), 420-434. 
10. Dadush, S. (2015.). Regulating Social Finance: Can Social Stock Exchanges Meet the Challenge? University of Pennsylvania Journal of International Law, 37(1), 139-230.

11. Daszynska-Zygadlo, K., Marszalek, J. i Piontek, K. (2018.). Sustainable Finance Instruments' Risk - Green Bond Market Analysis. European Financial Systems 2018: Proceedings of the 15th International Scientific Conference, 78-85, 25.-26. lipnja 2018., Brno.

12. Dayson, C., Fraser, A. i Lowe, T. (2019.). A Comparative Analysis of Social Impact Bond and Conventional Financing Approaches to Health Service Comissioning in England: The Case of Social Prescribing. Journal of Comparative Policy Analysis: Research and Practice, 1-17, rad prihvaćen za objavu.

13. Dečman, N., Švigir, A. i Rep, A. (2019.). Uloga nefinancijskih informacija u poslovnom odlučivanju u ovisnosti o karakteristikama poduzeća. Zbornik Ekonomskog fakulteta u Zagrebu, 17(1), 1-7.

14. Desai, V. M. (2018.). Collaborative Stakeholder Engagement: An Integration Between Theories of Organizational Legitimacy and Learning. Academy of Management Journal, 61(1), 220-244.

15. Deutsche Boerse Group (2019a.). About Us. Dostupno na http://deutsche-boerse.com/ dbg-en/about-us/deutsche-boerse-group.

16. Deutsche Boerse Group (2019b.). Stakeholders. Dostupno na https://www.deutsche-boerse.com/dbg-en/sustainability/materiality-analysis/stakeholders.

17. Deutsche Boerse Group (2019c.). Annual Report 2018. Deutsche Borse Group, Frankfurt/Main.

18. Donaldson, T. i Preston, L. E. (1995.). The Stakeholder Theory of the Corporation: Concepts, Evidence, and Implications. Academy of Management Review, 20(1), 65-91.

19. European Commission (2017.). Financing a Sustainable European Economy, EU high-level expert group on sustainable finance, Interim Report. Dostupno na https:// ec.europa.eu/info/sites/info/files/170713-sustainable-finance-report_en.pdf.

20. European Fund and Asset Management Association - EFAMA (2016.). Report on Responsible Investment. Dostupno na https://www.efama.org/Publications/EFAMA_ Responsible\%20Investment\%20Report_September\%202016.pdf.

21. Europska komisija (2018.). Akcijski plan o financiranju održivog razvoja. COM(2018) 97 final. Retrieved from https://eur-lex.europa.eu/legal-content/HR/TXT/HTML/?uri=CELEX:52018DC0097\&from=EN.

22. Fatima, A. H., Abdullah, N. i Sulaiman, M. (2015.). Environmental disclosure quality: examining the impact of the stock exchange of Malaysia's listing requirements. Social Responsibility Journal, 11(4), 904-922.

23. Freeman, R. E. (1984.). Strategic Management: A Stakeholder Approach. The Academy of Management Review, 24(2), 233-236.

24. Gifford, J. (2010.). Effective shareholder engagement: the factors that contribute to shareholder salience. Journal of Business Ethics, 92(S1), 79-97.

25. Global Reporting Initiative - GRI (2018.). GRI Standards. Global Reporting Initiative, Amsterdam. 
26. Global Reporting Initiative - GRI (2019.). About GRI, Global Reporting Initiative. Dostupno na https://www.globalreporting.org/information/about-gri/Pages/default. aspx.

27. Hartzell, J. (2007.). Creating an Ethical Stock Exchange. Saïd Business School, Oxford University. Dostupno na http://www.sbs.ox.ac.uk/sites/default/files/Skoll_ Centre/Docs/Ethical\%20stock\%20exchange.pdf.

28. Herzig, C. i Moon, J. (2013.). Discourses on corporate social responsibility in the financial sector. Journal of Business Research, 66(10), 1870-1880. Horn, R., de Klerk, M. i de Villiers, C. (2018.). The association between corporate social responsibility resporting and firm value for South African firms. South African Journal of Economic and Management Sciences, 21(1), 1-10.

29. Ivanišević Hernaus, A. (2013.). Razvoj društveno odgovornih financijskih ulaganja prijenom različitih strategija ulaganja (doktorski rad). Ekonomski fakultet Sveučilišta u Zagrebu, Zagreb.

30. Ivanišević Hernaus, A. (2019.). Exploring the strategic variety of socially responsible investment: Financial performance insights about SRI strategy portfolios. Sustainability Accounting, Management and Policy Journal, 10(3), 545-569.

31. Janik, B. i Bartkowiak, M. (2015.). The comparison of socially responsible indices in Central and Eastern Europe. International Journal of Environmental Technology and Management, 18(2), 153-169.

32. Klagge, B. i Zademach, H.-M. (2018.). International capital flows, stock markets, and uneven development: the case of Sub-Saharan Africa and the Sustainable Stock Exchanged Initiative (SSEI). Zeitschrift fuer Wirtschaftsgeographie, 62(2), 92-107.

33. Magness, V. (2008.). Who are the stakeholders now? An empirical examination of the Mitchell, Agle, and Wood theory of stakeholder salience. Journal of Business Ethics, 83(2), 177-192.

34. Mitchell, R. K., Agle, B. R. i Wood, D. J. (1997.). Toward a theory of stakeholder identification and salience: Defining the principle of who and what really counts. Academy of Management Review, 22(4), 853-886.

35. Neville, B., Bell, S. J. i Whitwell, G. (2011.). Stakeholder salience revisited: Refining, redefining, and refueling an underdeveloped conceptual tool. Journal of Business Ethics, 102(1), 357-378.

36. Ng, A.W. (2018.). From sustainability accounting to a green finance system: Institutional legitimacy and market heterogeneity in a global financial centre. Journal of Cleaner Production, 195, 585-592.

37. Ng, A. W. (2019.). Socially Responsible Investing in Sustainable Development. U: Leal Filho, W (ur.), Encyclopedia of Sustainability in Higher Education, Springer Nature, Ženeva.

38. OECD (2015.). Social Impact Investment: Building the Evidence Base. OECD Publishing, Pariz.

39. OECD (2019.). Social Impact Investment: The Impact Imperative for Sustainable Development. Organisation for Economic Co-operation and Development, Pariz. 
40. Oh, C. H., Park, J. H. i Ghauri, P. N. (2013.). Doing right, investing right: Socially responsible investing and shareholder activism in the financial sector. Business Horizons, 56(6), 703-714.

41. Ortas, E. i Moneva, J. M. (2011.). Sustainability stock exchange indexes and investor expectations: Multivariate evidence from DJSI-Stoxx. Revista Espanola de Financiacion y Contabilidad-Spanish Journal of Finance and Accounting, 40(151), 395-416.

42. Pauly, M. V. i Swanson, A. (2017.). Social Impact Bonds: New Product or New Package? Journal of Law, Economics and Organization, 33(4), 718-760.

43. Principles for Responsible Investment - PRI (2019.). What are the Principles for Responsible Investment? Dostupno na https:/www.unpri.org/

44. Sandberg, J. (2013.). (Re-)Interpreting fiduciary duty to justify socially responsible investment for pension funds? Corporate Governance: An International Review, 21(5), 436-446.

45. Sustainable Stock Exchange Initiative - SSEI (2015.). Sustainable Development Goals for Stock Exchanges. Dostupno na https://sseinitiative.org/ourwork/sdgs/.

46. Sustainable Stock Exchange Initiative - SSEI (2017.). How Stock Exchanges Can Grow Green Finance: A Voluntary Action Plan. Sustainable Stock Exchanges Initiative. Dostupno na https://sseinitiative.org/wp-content/uploads/2017/11/SSE-Green-Finance-Guidance-.pdf.

47. Sustainable Stock Exchange Initiative - SSEI (2018.). 2018 Report on Progress. Sustainable Stock Exchanges Initiative. Dostupno na https://sseinitiative.org/wp-content/uploads/2018/10/SSE_On_Progress_Report_FINAL.pdf.

48. Taraktas, A. (2015). Social Impact Bonds as an Innovative Finance Tool for Social Projects of Local Governments; Recommendations for Turkey. Maliye Dergisi, 168, 31-48.

49. Thornley, B., Wood, D., Grace, K. i Sullivant, S. (2011.). Impact Investing: A Framework for Policy Design and Analysis. Pacific Community Ventures, Institute for Responsible Investment. Harvard University and Rockefeller Foundation, January.

50. Ujedinjeni narodi (2019a.). Sustainable Development Agenda. Dostupno na https:// www.un.org/sustainabledevelopment/development-agenda/.

51. Ujedinjeni narodi (2019b.). The Sustainable Development Goals Report 2019. Ujedinjeni narodi, New York.

52. UNCTAD i WFE (2017.). The Role of Stock Exchanges in Fostering Economic Growth and Sustainable Development. The United Nations Conference on Trade and Development and The World Federation of Exchanges, New York.

53. UNEP (2017.). Financial Centres for Sustainability: Reviewing G7 Financial Centres in Mobilizing Green and Sustainable Finance. United Nations Environment Program. Dostupno na http://unepinquiry.org/wp-content/uploads/2017/06/Financial_Centres_ for_Sustainability.pdf.

54. United Nations Global Compact (2018.). Communication on Progress 2018. Deutsche Boerse Group. Dostupno na www.deutsche-boerse.com.

55. Vezer, M., David, T., Ranney, K. i Morrow, D. (2017.). How Investors Investigate ESG: A Typology of Approaches. The Investor Responsibility Research Center Institute. 
Dostupno na https://www.sustainalytics.com/esg-research/thematic-reports/how-investors-integrate-esg-typology-irrci/.

56. Vives, A. i Badhwa, B. (2012.). Sustainability indices in emerging markets: impact on responsible practices and financial market development. Journal of Sustainable Finance \& Investment, 2(3-4), 318-337.

57. Wagemans, F. A. J., van Koppen, C. i Mol, A. P. J. (2013.). The effectiveness of socially responsible invetment: a review. Journal of Integrative Environmental Sciences, 10(3-4), 235-252.

58. Wendt, K. (2017.). Social Stock Exchanges: Democratization of Capital Investing for Impact. 30th Australasian Finance and Banking Conference.

59. Wisniewski, M. i Zielinski, J. (2019.). Green bonds as an innovative sovereign financial instrument. Ekonomia i prawo-Economics and Law, 18(1), 83-96.

60. Woods, C. i Urwin, R. (2010.). Putting sustainable investing into practice: A governance framework for pension funds. Journal of Business Ethics, 92(1), 1-19.

61. World Federation of Exchanges (2019.). Statistics. Dostupno na: https://statistics.world-exchanges.org/ReportGenerator/Generator. 